\title{
SOSIALISASI KPU KABUPATEN SIJUNJUNG DALAM UPAYA MENINGKATKAN PARTISIPASI PEMILIH DALAM PILKADA TAHUN 2015
}

\author{
Dedi Triralmaidi ${ }^{1)}$, Alfan Miko, ${ }^{2)}$, Asrinaldi ${ }^{3)}$ \\ 1,2,3) Megister Kosentrasi Tata Kelola Pemilu Fakultas Ilmu Sosial Dan Ilmu Politik \\ Universitas Andalas, Padang, Indonesia
}

\begin{abstract}
Abstrak
Sosialisasi Pilkada dilaksanakan oleh Penyelenggara Pemilu sebagai upaya dalam meningkatkan peran serta masyarakat dalam Pemilu dan mewujudkan Pemilu yang berintegritas. Namun permasalahan mengenai sosialisasi terutama partisipasi masyarakat dalam Pilkada yang dilakukan secara luas dan efektif yang akan menentukan kualitas partisipasi pemilih masih menjadi pekerjaan rumah tersendiri bagi Penyelenggara Pemilu. Untuk Kabupaten Sijunjung, dalam tiga kali periode pelaksanaan Pilkada yaitu tahun 2005, tahun 2010, dan tahun 2015 selalu menunjukkan angka partisipasi masyarakat yang terus menurun. Untuk itu, tujuan dari penelitian ini adalah untuk mendeskripsikan dan menjelaskan apa saja dan bagaimana Sosialisasi KPU Kabupaten Sijunjung dalam upaya Untuk Meningkatkan Partisipasi Pemilih Pada Pemilihan Bupati dan Wakil Bupati Sijunjung Tahun 2015. Penelitian ini menggunakan data primer yang diperoleh dengan wawancara langsung serta data sekunder menggunakan artikel, sumber tertulis terutama sumber online yang relevan. Jenis penelitian yang digunakan adalah penelitian deskriptif kualitatif yaitu penelitian yang berusaha menggambarkan atau mendeskripsikan obyek yang diteliti berdasarkan fakta yang ada di lapangan. Menggunakan analisis data dengan metode Miles dan Huberman yaitu analisis data yang diawali dengan proses pengumpulan, reduksi, dan penyajian data serta penarikan kesimpulan.
\end{abstract}

Kata Kunci: Sosialisasi, Partisipasi Pemilih, KPU, Pilkada

*Correspondence Address : deditriralmaidi@yahoo.com DOI : 10.31604/jips.v6i2.2019. 282-297

(C)2019 Fakultas Keguruan \& Ilmu Pendidikan UM-Tapanuli Selatan 


\section{PENDAHULUAN}

Pemilihan Umum merupakan sarana untuk mewujudkan kedaulatan rakyat sebagai wujud keikutsertaan seluruh rakyat Indonesia dalam penyelenggaraan Pemerintahan negara berdasarkan Undang- Undang Dasar 1945. Partisipasi politik dalam negara demokrasi merupakan indikator implementasi penyelenggaraan kekuasaan negara tertinggi yang absah oleh rakyat (kedaulatan rakyat), yang dimanifestasikan keterlibatan mereka dalam pesta demokrasi (pemilu). Makin tinggi tingkat partisipasi politik mengindikasikan bahwa rakyat mengikuti dan memahami serta melibatkan diri dalam kegiatan kenegaraan. Sebaliknya tingkat partsipasi politik yang rendah pada umumnya mengindikasikan bahwa rakyat kurang menaruh apresiasi atau minat terhadap masalah atau kegiatan kenegaraan. Rendahnya tingkat partisipasi politik rakyat direfleksikan dalam sikap golongan putih (golput) dalam pemilu.

Pemilihan Kepala Daerah dan Wakil Kepala Daerah Serentak Tahun 2015 adalah salah satu wujud nyata pesta demokrasi bagi seluruh rakyat Indonesia khususnya di daerah untuk memilih pemimpinnya secara langsung guna mewujudkan aspirasi dan keinginan rakyat. Pemilihan kepala daerah dan wakil kepala daerah yang dilaksanakan secara langsung di Indonesia adalah sebuah konsekuensi dari tuntutan demokrasi, agenda reformasi, dan desentralisasi. Setelah munculnya Undang-Undang Nomor 32 Tahun 2004 tentang Pemerintahan Daerah, maka pelaksanaan pemilihan kepala daerah (Pilkada) dilakukan secara langsung dimana sebelum adanya undang-undang tersebut pelaksanaan pemilihan kepala daerah dilakukan oleh legislatif.

Pemilihan langsung kepala daerah (pilkada langsung) merupakan kerangka kelembagaan baru dalam rangka mewujudkan proses demokratisasi di daerah. Proses ini diharapkan bisa mereduksi secara luas adanya pembajakan kekuasaan yang dilakukan oleh partai politik yang memiliki kursi di Dewan Perwakilan Rakyat Daerah (DPRD). Selain itu, pilkada secara langsung juga diharapkan bisa menghasilkan kepala daerah yang memiliki akuntabilitas lebih tinggi kepada rakyat.

Khususnya di Kabupaten Sijunjung, Pemilihan Kepala Daerah dan Wakil Kepala Daerah serentak Tahun 2015 sebagai pelaksana roda pemerintahan juga dilaksanakan secara 
serentak sesuai dengan jadwal yang telah ditetapkan pada tanggal 9 Desember 2015. Pada seluruh rangkaian tahapan yang diselenggarakan dalam Pemilihan Kepala Daerah dan Wakil Kepala Daerah Kabupaten Sijunjung Tahun 2015 tentunya diharapkan terciptanya partisipasi masyarakat yang tinggi sebagai cerminan suksesnya pelaksanaan pemilihan tersebut.

Pada pelaksanaan Pemilihan Kepala Daerah dan Wakil Kepala Daerah di Kabupaten Sijunjung Tahun 2015 , partisipasi masyarakat relatif lebih rendah dibandingkan dengan Pemilihan Kepala Daerah dan Wakil Kepala Daerah pada tahun 2005 dan 2010 dan cenderung menunjukkan grafik yang menurun pada tiap periode berikutnya. Pada Pemilihan Bupati dan Wakil Bupati Sjunjung tahun 2005 menunjukkan jumlah partisipasi masyarakat sebesar $70,91 \quad \% \quad$ (81.086 jiwa yang menggunakan hak pilih dari total 114.375 pemilih). Pada pelaksanaan Pemilihan Bupati dan Wakil Bupati Sjunjung tahun 2010 jumlah partisipasi masyarakat sebesar 67,02 \% (90.470 jiwa yang menggunakan hak pilih dari total 134.980 pemilih). Sedangkan untuk pelaksanaan Pemilihan Bupati dan Wakil Bupati Sjunjung tahun 2015 jumlah partisipasi masyarakat sebesar
$58,48 \quad \% \quad$ (87.999 jiwa yang menggunakan hak pilih dari total 149.321 pemilih).

Sehubungan dengan permasalahan diatas, menarik untuk dibahas lebih mendalam tentang Apa saja dan bagaimana Sosialisasi yang telah dilakukan oleh KPU Kabupaten Sijunjung dalam upaya Meningkatkan Partisipasi Pemilih Pada Pemilihan Bupati dan Wakil Bupati Sijunjung Tahun 2015.

\section{Metode Penelitian}

Metode yang digunakan dalam penelitian adalah kualitatif deskriptif. Analisis data yang digunakan dalam penelitian ini menggunakan metode analisis data kualitatif yaitu mendeskripsikan serta menganalisis data dan sumber data yang diperoleh kemudian dijabarkan dalam bentuk penjelasan yang sebenarnya. Analisis data yang digunakan dalam penelitian ini adalah metode analisis data deskritif kualitatif dari Milles dan Huberman (dalam Tjetjep Rohendi Rohidi 2009:1520) yang meliputi empat komponen yaitu:

1. Pengumpulan data (data collecting) yaitu pengumpulan data pertama atau data mentah yang dikumpulkan dalam suatu penelitian. 
2. Reduksi data (data reduction) yaitu proses memilih, memfokuskan, menyederhanakan, dengan membuatabstraksi, mengubah data mentah menjadi yang dikumpulkan dari penelitian kedalam catatan yang telah diperiksa.

3. Penyajian data (data display) yaitu menyusun informasi dengan cara tertentu sehingga diperlukan penarikan kesimpulan atau pengambilan tindakan.

4. Penarikan kesimpulan (conclutions drawing) yaitu proses mencari arti benda-benda, mencatat keteraturan, pola-pola, penjelasan konfigurasi yang mungkin terjadi, sebab akibat dan proposi penelitian. Kesimpulan juga diverifikasi selama penelitian berlangsung.

\section{PEMBAHASAN}

\section{Sosialisasi}

Sosialisasi merupakan suatu proses dimana seseorang melakukan internalisasi konsep, nilai nilai, ide atau gagasan kepada orang lain dalam suatu kelompok atau institusi sosial sehingga memunculkan partisipasi (keikutsertaan) di dalam kelompok atau institusi sosial tersebut.

James W. Vander Zanden mendefenisikan sosialisasi sebagai "suatu proses interaksi sosial dengan mana orang memperoleh pengetahuan, sikap, nilai, dan perilaku essensial untuk keikutsertaan (partisipasi) efektif dalam masyarakat. Sosialisasi diartikan sebagai sebuah proses seumur hidup bagaimana seorang individu mempelajari kebiasaan-kebiasaan yang meliputi caracara hidup, nilai-nilai, dan norma-norma sosial yang terdapat dalam masyarakat agar dapat diterima oleh masyarakatnya. Secara umum sosialisasi didefinisikan sebagai proses penanaman atau transfer kebiasaan atau nilai dan aturan dari satu generasi kegenerasi lainnya dalam sebuah kelompok atau masyarakat. Sosialisasi juga dikenal sebagai teori mengenai peranan (role theory). Karena dalam proses sosialisasi diajarkan peran-peran yang harus dijalankan oleh individu.

\section{Menurut David A. Goslin} berpendapat "Sosialisasi adalah proses belajar yang di alami seseorang untuk memperoleh pengetahuan ketrampilan, nilai-nilai dan norma-norma agar ia dapat berpartisipasi sebagai anggota dalam kelompok masyarakatnya."

Menurut Narwoko dan Bagong dalam "Sosiologi Teks Pengantar dan Terapan" proses sosialisasi yang ternyata relavan bagi pembentukan kepribadian dapat dibedakan atas: 
a. Proses sosialisasi yang dikerjakan (tanpa sengaja) lewat proses interaksi sosial.

b. Proses sosialisasi yang dikerjakan (secara sengaja) lewat proses pendidikan dan pengajaran.

\section{Sosialisasi Politik}

Sosialisasi politik, menurut Hyman merupakan suatu proses belajar yang kontinyu yang melibatkan baik belajar secara emosional (emotional learning) maupun indoktrinasi politik yang manifes (nyata) dan dimediai (sarana komunikasi) oleh segala partisipasi dan pengalaman si individu yang menjalaninya. Pengertian sosialisasi politik secara sederhana dapat dipahami melalui menambahkan atau mengaitkan definisi yang ada tentang sosialisasi dengan politik. Jika didefenisikan dengan mengaitkan pengertian sosialisasi dengan politik, maka sosialisasi politik dapat diartikan sebagai suatu proses melakukan internalisasi konsep, nilai-nilai, ide atau gagasan, pengetahuan, sikap dan perilaku untuk memunculkan keikutsertaan (partisipasi) efektif di dalam kelompok atau institusi politik. apabila defenisi sosiologi politik dikonstruksi berdasarkan kesimpulan kita tentang sosialisasi di atas, maka sosialisasi politik adalah suatu transmisi pengetahuan, sikap, nilai, norma dan perilaku essensial dalam kaitannya dengan politik, agar mampu berpartisipasi efektif dalam kehidupan politik.

Menurut Efrizal sosialisasi politik merupakan suatu proses bagaimana memperkenalkan system politik pada seseorang, dan bagaimana orang tersebut menentukan tanggapan serta reaksi-reaksinya terhadap gejala-gejala politik. Sedangkan menurut Syarial dalam Efrizal sosialisasi politik ialah proses pembentukan sikap dan orientasi politik pada anggota masyarakat. Melalui proses sosialisasi politik inilah masyarakat memperoleh sikap dan orientasi terhadap kehidupan politik yang berlangsung dalam masyarakat.

Berdasarkan penjelasan diatas menurut penulis bahwa sosialisasi politik merupakan suatu proses sosial yang didalamnya melakukan sosialisasi secara langsung kepada masyarakat guna mendapatkan informasi dibidang politik yang erat kaitannya dengan pemilu.

\section{Pendidikan Politik}

Menurut Rusadi Kantaprawira, pendidikan politik yaitu untuk 
meningkatkan pengetahuan rakyat agar mereka dapat berpartisipasi secara maksimal dalam sistem politiknya. Sesuai paham kedaulatan rakyat atau demokrasi, rakyat harus mampu menjalankan tugas partisipasi. Selanjutnya untuk tujuan pendidikan politik bagi generasi muda dituangkan dalam Inpres No. 12 Tahun 1982 tentang Pendidikan Politik bagi Generasi Muda yang menyatakan bahwa: Tujuan pendidikan politik adalah memberikan pedoman kepada generasi muda Indonesiaguna meningkatkan kesadaran kehidupan berbangsa dan bernegara. Sedangkan tujuan pendidikan politik lainnya ialah menciptakan generasi muda Indonesia yang sadar akankehidupan berbangsa dan bernegara berdasarkan Pancasila dan UUD 1945 sebagai salah satu usaha untuk membangun manusia Indonesia seutuhnya.

\section{Pemilihan Umum dan Pemilihan} Umum Kepala Daerah (Pilkada)

Menurut Gaffar pemilu adalah sarana utama mewujudkan demokrasi dalam suatu negara. Substansi pemilu adalah penyampaian suara rakyat untuk membentuk lembaga perwakilan dan pemerintahan sebagai penyelenggara negara. Suara rakyat diwujudkan dalam bentuk hak pilih, yaitu hak untuk memilih wakil dari berbagai calon yang ada. Sedangkan menurut Efriza, pemilu merupakan cara yang terkuat bagi rakyat untuk berpartisipasi didalam sistem demokrasi perwakilan modern.

Dari pendapat diatas dapat disimpulkan bahwa pemilihan umum adalah sarana demokrasi untuk membentuk suatu sisitem kekuasaan negara yang lahir dari rakyat dan menurut kehendak rakyat yang dipraktekkan dalam bentuk perwakilan yang didalamnya terdapat kompetisi politik yang dilaksanakan secara adail dan terbuka dalam pelaksanaanya.

Menurut Joko J. Prihatmoko Pemilihan kepala daerah, baik gubernur maupun bupati/walikota secara langsung merupakan perwujudan pengembalian hak-hak dasar dalam memilih pemimpin di daerah. Dengan demikian, rakyat memiliki kesempatan dan kedaulatan untuk menentukan pemimpin daerah secara langsung, bebas, dan rahasia tanpa adanya intervensi sama halnya mereka memilih prasiden dan wakil presiden dan wakilwakilnya di legislatif dalam pemilu.

\section{Komisi Pemilihan Umum}

Menurut Ferry Kurnia Rizkiyansyah menyebutkan bahwa yang 
dimaksud dengan penyelenggara pemilihan umum adalah suatu lembaga khusus yang menangani proses pemilihan umum. Definisi di atas menyebutkan bahwa penyelenggara pemilihan umum adalah lembaga khusus yang menangani proses pemilihan umum. Komisi pemilihan umum merupakan lembaga khusus yang menangani proses pemilihan umum di Indonesia. Komisi pemilihan umum sesuai dengan amanat UUD 1945 merupakan lembaga khusus penyelenggara pemilihan umum yang bersifat nasional, tetap dan mandiri.

\section{Partisipasi Politik}

Partisipasi merupakan salah satu aspek penting demokrasi. Partisipasi merupakan taraf partisipasi politik warga masyarakat dalam kegiatankegiatan politik baik yang bersifat aktif maupun pasif dan bersifat langsung maupun yang bersifat tidak langsung guna mempengaruhi kebijakan pemerintah.

Menurut Kumoroto menyatakan bahwa Partisipasi adalah berbagai corak tindakan massa maupun individual yang memperlihatkan adanya hubungan timbal balik antara pemerintah dan warganya corak partisipasi warga negara dibedakan menjadi empat macam, yaitu : pertama, partisipasi dalam pemilihan (electoral participation), kedua, partisipasi kelompok (group participation), ketiga, kontak antara warga negara dengan warga pemerintah (citizen government contacting) dan keempat, partisipasi warga negara secara langsung.

Adapun bentuk-bentuk partisipasi politik dalam pemilu menurut Dedi Irawan dalam Efriza, yaitu

1. Voting ( pemberian suara) : Voting adalah bentuk partisipasi yang dapat diukur dengan skala waktu atau periodisasi. Pemberian suara pada pemilu legislatif, pemilu presiden dan wakil presiden, pemilihan kepala daerah, pemilihan kepala desa, dll.

2. Kampanye Politik : Kampanye adalah kegiatan politik yang bertujuan untuk memengaruhi orang atau kelompok lain agar orang lain atau kelompok lain tersebut mengikuti kegiatan politik pihak yang berkampanye (misalnya dalam pemilu).

3. Aktivitas Group : Kegiatan politik yang digerakkan oleh sebuah kelompok secara sistematis. Misalnya saja demonstrasi, aksi 
menuntut perubahan politik, terror dan intimidasi, diskusi politik, dll.

4. Kontak Politik : Kegiatan politik yang biasanya dilakukan oleh individu-individu untuk melakukan komunikasi politik kepada pimpinan parpol, elit politik, dll.

Selain bentuk partisipasi diatas, ilmuan politik mengidentifikasi beberapa kecenderungan perilaku politik masyarakat, Michael Rush dan Althoff menyebutkan sebagai berikut :

a. Apatis (masa bodoh) dapat diartikan sebagai tidak punya minat atau tidak punya perhatian terhadap orang lain, situasi, atau gejala-gejala.

b. Sinisme diartikan sebagai "kecurigaan yang busuk dari manusia", dalam hal ini dia melihat bahwa politik adalah urusan yang kotor, tidak dapat dipercaya, dan menganggap partisipasi politik dalam bentuk apa pun sia-sia dan tidak ada hasilnya.

c. Alienasi sebagai perasaan keterasingan seseorang dari politik dan pemerintahan masyarakat dan kecenderungan berpikir mengenai pemerintahan dan politik bangsa yang dilakukan oleh orang lain untuk oranng lain tidak adil.

d. Anomie sebagai suatu perasaan kehidupan nilai dan ketiadaan awal dengan kondisi seorang individu mengalami perasaan ketidak efektifan dan bahwa para penguasa bersikap tidak peduli yang mengakibatkan devaluasi dari tujuan-tujuan dan hilangnya urgensi untuk bertindak.

\section{Pemilih}

Menurut UU No 8 tahun 2012 pemilih adalah warga Negara Indonesia yang telah genap berumur 17 tahun, atau sudah pernah kawin. Tetapi dalam pelaksanaan pemilu yang berhak memberikan hak pilihnya adalah pemilih tersebut tidak sedang terganngu jiwanya, tidak dicabut hak pilihnya atas putusan pengadilan, pemilih tersebut tidak masuk dalam kategori TNI/POLRI. Pemilih yang memenuhi sayarat akan di daftar sebagai pemilih di masukan dalam Daftar Pemilih Tetap arau DPT yang kemudian ditetapkan ditetapkan oleh komisi pemilihan umum (KPU) Pemilih merupakan bagian masyarakat luas yang bisa saja tidak menjadi konstituen partai politik tertentu. Masyarakat terdiri dari beragam kelompok, terdapat kelompok masyarakat yang memang non partisipan, dimana ideologi dan tujuan politik mereka tidak dikatakan kepada suatu partai politik tertentu . Mereka 
menunggu sampai ada satu partai politik yang bisa menawarkan program kerja yang terbaik menurut mereka, sehingga partai tersebutlah yang akan mereka pilih.

\section{a. Program Sosialisasi KPU Sijunjung Pada Pilkada Tahun 2015}

\section{Sosialisasi Tatap Muka}

Kegiatan sosialiasi tatap muka pada masyarakat merupakan salah satu kegiatan sosialisasi yang dilakukan KPU Kabupaten Sijunjung dalam menyampakan informasi seputar pelaksanaan pemilihan Bupati dan Wakil Bupati Sijunjung Tahun 2015. Sosialiasi tatap muka merupakan bagian dari komunikasi antarpribadi yang umumnya berlangsung secara langsung tanpa melalui perantara. Ada beberapa kelompok sasaran masayarakat dalam melakukan sosialisasi tatap muka ini :

1. Palanta Demokrasi

Palanta demokrasi ini merupakan prototipe sosialisasi yang merakyat, mengakar, dan populis. KPU Sijunjung dalam mengadakan Sosialisasi ini langsung mendatangi basis massa, tidak lagi sepenuhnya menerapkan pola mengundang kalangan elit elemen masyarakat ke kantor KPU Sijunjung, gedung atau hotel, melainkan KPU Sijunjung duduk bersama dimana biasanya masyarakat duduk, bicara dan diskusi dimana biasanya mereka diskusi.

Konsep dasar program ini adalah dimana lapau atau kedai adalah salah satu tempat berkumpul dan bercerita di daerah Minangkabau ini. Di lapau ini, orang membahas berbagai persoalan kehidupan. Di tempat minum kopi ini, masyarakat Minang mendiskusikan isuisu hangat yang sedang berkembang baik itu di kampung sendiri ataupun bahkan sampai isu nasional dan internasional. Dan di kedai ini pula masyarakat paling seru membahas politik dan demokrasi.

Format acaranya dibuat layaknya seperti cerita di kedai pada umumnya dengan suasana santai, informal, egaliter dengan suguhan kopi dan gorengan namun tetap terarah metode Focus Group Discussion (FGD). Sehingga, ujung dari setiap yang dibahas, ada kesimpulan. Ada kaidah aturan yang disampaikan. Segala yang didiskusikan tidak lepas kemana-mana, tetapi mengacu kepada guideline Pilkada serentak 2015 dan demokrasi.

Sosialisasi Palanta Demokrasi yang dilakukan KPU kabupaten Sijunjung ini dilaksanakan pada setiap kecamatan di Kabupaten Sijunjung yaitu pada delapan kecamatan dengan 
hari yang berbeda. Acaranya melibatkan para tokoh-tokoh masyarakat baik yang dari Kabupaten maupun dari kecamatan. Acara ini juga disiarkan secara langsung oleh Radio Lansek Manih Sijunjung yang merupakan radio lokal di Sijunjung sehinggga acara ini dapat didengar oleh seluruh masyarakat Sijunjung guna lebih mengefektifkan ssialisasi tersebut.

2. Sosialisasi kepada Kelompok masyarakat atau Komunitas

Sosialisasi lainnya terkait Pilkada Tahun 2015 yang dilakukan oleh KPU Sijunjung adalah dengan cara melakukan pertemuan-pertemuan dengan kelompok-kelompok masyarakat atau komunitas masyarakat yang ada di setiap kecamatan di Kabupaten Sijunjung. Dalam pertemuan dengan kelompok masyakat ini, KPU Sijunjung berdiskusi langsung dan mengajak masyarakat untuk berpartisipasi aktif dalam Pilkada Sijunjung Tahun 2015. Artinya, komunitas masyarakat yang mendapatkan sosialisasi dari KPU Sijunjung ini, selanjutnya diharapkan juga memberikan dan melanjutkan sosialisasi dan informasi terkait Pilkada Sijunung tahun 2015 ini kepada masyarakat lain di sekitar mereka.
Adapun kelompok-kelompok masyarakat yang diberikan sosialisasi oleh KPU Kabupaten Sijunjung diantaranya, Kelompok pembuat Tikar Pandan di Nagari Padang Laweh, Kelompok Perempuan Kepala Rumah Tangga di Nagari Kamang, Kelompok Tani di Nagari Tanjung Gadang, kelompok Majelis Taklim, dan kelompok masyarakat lainnya di wilayah Kabupaten Sijunjung.

3. Pembentukan Relawan Demokrasi Program relawan demokrasi adalah gerakan sosial yang dimaksudkan untuk meningkatkan partisipasi dan kualitas pemilih dalam menggunakan hak pilih. Program ini melibatkan peran serta masyarakat yang seluas-luasnya dimana mereka ditempatkan sebagai pelopor (pioneer) demokrasi bagi komunitasnya. Relawan demokrasi menjadi mitra KPU Kabupaten Sijunjung dalam menjalankan agenda sosialisasi dan pendidikan pemilih berbasis Nagari. Bentuk peran serta masyarakat ini diharapkan mampu mendorong tumbuhnya kesadaran tinggi serta tanggung jawab penuh masyarakat untuk menggunakan haknya dalam pemilu secara optimal.

Salah satu tugas pokok Agen Sosialisasi dan Relawan Demokrasi 
pada Pilkada Kabupaten Sijunjung tahun 2015 adalah membantu KPU Kabupaten Sijunjung dalam mensosialisasikan setiap tahapan Pemilukada. Dalam menjalankan tugasnya, relawan demokrasi dan agen sosialisasi menyampaikan tentang :

- Pentingnya demokrasi, Pemilu dan partisipasi politik masyarakat.

- Pemutakhiran data pemilih.

- Tata Cara pemberian suara pada pemilu.

- Pentingnya pengenalan terhadap kontestan Pemilu (Nama, Nomor urut, visi misi dan program).

- Bahaya sikap Golput (non-voting) dan politik uang (money Politic).

Sedangkan tujuan dari sosialisasi yang dilakukan oleh Relawan Demokrasi dan Agen Sosialisasi tersebut yakni :

- Meningkatkan poemahaman dan pengetahuan masyarakat akan pentingnya pemilu dalam membangun demokrasi di Indonesia.

- Meningkatkan poemahaman dan pengetahuan masyarakat tetang program, tahapaan, jadwal dan hasil Pemilu.

- Meningkatkan pemahaman dan pengetahuan masyarakat tetang beberapa hal teknis dalam menggunakan hak politik dan hak pilihnya dalam pemilu.

- Meningkatkan kesadaran masyarakat khususnya pemilih untuk berperan serta dalam setiap tahapan pemilu.

- Meningkatkan kesadaran dan partisipasi pemilih dalam mengguakan hak pilihnya pada Peilu, oleh karena terdapat indikasi penurunan partisipasi pemilih.

Program Relawan Demokrasi diharapkan mampu menumbuhkan kembali kesadaran positif terhadap pentingnya pemilu dalam kehidupan berbangsa dan bernegara. Pada akhirnya relawan demokrasi ini dapat menggerakan masyarakat tempat mereka berada, agar mau menggunakan hak pilihnya dengan bijaksana serta penuh tanggung jawab, sehingga partisipasi pemilih dan kualitas Pemilihan dapat lebih baik dibandingkan pemilu-pemilu sebelumnya.

\section{Sosialisasi Melalui Media}

Berbagai media komunikasi digunakan KPU Kabupaten Sijunjung dalam mensosialisasikan pelaksanaan Pemilihan Bupati dan Wakil Bupati Sijunjung tahun 2015 dalam upaya meningkatkan partisispasi pemilih. Penggunaan media seperti surat kabar, 
radio dan televisi sangat diperlukan untuk menjelaskan serta memberikan informasi kepada masyarakat yang tersebar tanpa harus ketemu secara langsung dimanapun mereka berada.

1. Media Audio

Media Komunikasi Audio yang digunakan oleh KPU Kabupaten dalam mensosialisasikan Pilkada Sijunjung Tahun 2015 adalah Radio. Radio lokal yang ada di Kabupaten Sijunjung diberdayakan untuk menyiarkan hal-hal terkait Pilkada Sijunjung Tahun 2015. Adapun salah satu acara yang disiarkan di Radio tersebut adalah berupa Talkshow yang diisi oleh komisioner KPU Kabupaten Sijunjung sebagai narasumber. Masyarakat juga dapat berinteraksi dan berdiskusi dalam acara tersebut melalui telepon saat acara sedang berlangsung. Program lainnya adalah dengan menyiarkan iklan-iklan pemilu melalui radio, pemutaran jingle pemilu melalui radio. Adapun radio yang memfasilitasi acara tersebut antara lain Lansek Manih FM, Sijma FM.

2. Media Visual

Dalam hal ini KPU kabupaten Sijunjung membuat spanduk, baliho, poster dan leaflet sebagai bahan sosialisasi yang disebarkan kepada masyarakat dan ditempelkan pada tempat-tempat tertentu yang strategis guna memberikan informasi terkait Pilkada Sijunjung Tahun 2015 kepada masyarakat sijunjung. Adapun informasi sosialisasi yang disebarkan berupa himbauan kepada masyarakat untuk menggunakan hak pilihnya pada 9 Desember 2015 untuk memilih Bupati dan Wakil Bupati Sijunjung periode 2016-2021. Serta juga menginformasikan tentang apakah masyarakat sudah terdaftar sebagai pemilih atau belum. Serta melalui Alat Peraga Kampanye (APK) yang difalitasi oleh KPU Sijunjung, secara tidak langsung juga mensosialisasikan kepada masyarakat Sijunjung tentang pasangan Calon Bupat dan Wakil Bupati Sijunjung Tahun 2015 beserta visi dan misinya.

3. Media Audio Visual

Konten-konten terkait Sosialisasi Pilkada Sijunjung Tahun 2015 juga dimuat dalam website resmi KPU Sijunjung yang berisikan tentang berita, kegiatan serta himbauan bagi masyarakat Sijunjung untuk berpartisipasi aktif dalam Pilkada Sijunjung Tahun 2015. Selain itu, KPU Sijunjung juga membuat sebuah film pendek yang bercerita tentang pentingnya berpartisipasi dalam Pilkada Sijunjung Tahun 2015 yang berjudul Si Mami "Sijunjuang Mamiliah" yang diupload ke youtube dengan alamat 
https://www.youtube.com/watch?v=1ph

C9wk7G6Q. Baik website dan film pendek tersebut guna Sosialisai Pemilihan Bupati dan Wakil Bupati Sijunjung Tahun 2015 yang dapat diakses bebas oleh masyarakat

\section{Pendidikan Pemilih Pemula}

1. Training Of Trainer kepada Guru PKn di Kabupaten Sijunjung

Komisi Pemilihan Umum (KPU) Kabupaten Sijunjung menjadikan guru Pendidikan Kewarganegaraan (PKn) Sekolah Lanjutan Tingkat Atas seKabupaten Sijunjung sebagai ujung tombak sosialisasi Pilkada 2015. Kehendak itu muncul secara sukarela dari para pahlawan tanpa tanda jasa ketika acara KPU Goes to Community di Muaro Sijunjung.

Jumlah guru PKn se-Kabupaten ada 27 orang untuk 25 sekolah. Secara matematis memang kuantitas ini tidak seberapa, tetapi yang diajar ada ribuan siswa yang notabene adalah masuk kategori pemilih pemula. Forum guru mata pelajaran PKn itu sangat efektif menjadi ujung tombak sosialisasi Pilkada serentak 2015, lantaran audiensnya jelas dan pengajarannya reguler dari segi waktu dan materi.

Dengan program ini, guru PKn seKabupaten Sijunjung dalam mata pelajaran PKn memberikan materi tentang pemilu dan terkhusus lagi terhadap sosialisasi pilkada tahun 2015 kepada adak didiknya yang merupakan pemilih pemula. Adapun penekanan sosialisasi tersebut adalah menanamkan bagaimana pentinganya partisipasi pemilih dalam pemilu dan pilkada serta pengenalan terhadap calon kepala daerah yang berkontestasi. KPU Sijunjung sebagai penyelenggara Pilkada di Kabupaten Sijunjung tentunya juga memberikan pendampingan terhadap berjalannya program ini. Salah satu agendanya adalah dengan menjadi guru tamu untuk mata pelajaran PKn.

2. Menjadi Pembina Upacara Pada Upacara Bendera di SekolahSekolah

Komisi Pemilihan Umum (KPU) Kabupaten Sijunjung, mengadakan sosialisasi kepada pemilih pemula dengan menjadi Pembina Upacara di sekolah-sekolah Menengah Tingkat Atas yang ada di Kabupaten Sijunjung. Lima orang komisioner KPU Kabupaten Sijunjung disebar pada lima sekolah sekaligus pada Upacara bendera hari senin pagi. Dan ini berlanjut sampai semua sekolah tingkat atas di Kabupaten Sijunjung terpenuhi. Adapun topik yang disampaikan pada kegiatan sosialisasi ini adalah pentingnya peran Pemilih Pemula dalam meningkatkan Partisipasi 
pada Pemilihan Bupati dan Wakil Bupati

Sijunjung Tahun 2015. Serta mensosialisasikan apakah mereka sudah terdaftar menjadi pemilih dan juga mengenalkan daftar pasangan calon Bupati dan Wakil Bupati Sijunjung yang ikut dalam Pilkada Tahun 2015.

\section{Sosialisasi dalam bentuk Pesta Rakyat}

1. Deklarasi Damai dan Karnaval

Acara deklarasi damai dan karnaval Pilkada Kabupaten Sijunjung diadakan di Halaman Kantor Bupati Sijunjung. Acara ini dihadiri oleh semua peserta calon Bupati dan Wakil Bupati, unsur Muspida, para tokoh masyarakat sijunjung, KPU, Bawaslu, para undangan dan dapat disaksikan langsung oleh masyarakat luas.

Format acaranya adalah penandatangan ikrar pemilu damai dari semua calon yang menunjukkan komitmen mereka untuk mewujudkan pilkada yang aman dan damai di Kabupaten Sijunjung. Setelah acara penandatanganan, semua peserta pilkada sijunjung tahun 2015 mengikuti kirab karnaval yang mengelilingi jalanjalan protokol di kabupaten Sijunjung dengan menggunakan arak-arakan mobil hias dan tim kampanyenya. Hal ini untuk menunjukkan

dan memperkenalkan para calon kepada masyarakat dan juga menghimbau masyarakat Sijunjung untuk berpartisipasi dalam Pilkada Sijunjung Tahun 2015.

2. Jalan Sehat Pilkada Sijunjung Tahun 2015

Senam Massal dan Jalan Sehat Pilkada Sijunjung 2015 dimaksudkan sebagai momentum untuk memperat rasa kekeluargaan, baik pasangan calon, partai pengusung, penyelenggara dan masyarakat luas. Acara ini dilaksanakan Satu bulan menjelang hari pemunggutan suara, kegiatan berkumpul dalam suasana bertabur hadiah dan tawa serta kekompakan ini menjadi hal penting Karena merupakan refleksi dari Pilkada badunsanak. Acara ini juga berguna untuk mengingatkan dan menghimbau masyarakat Kabupaten Sijunjung untuk menggunakan hak pilihnya dan berpartisipasi dalam Pemilihan Bupati dan Wakil Bupati Sijunjung Tahun 2015.

\section{KESIMPULAN DAN SARAN}

Sosialisasi politik dalam Pilkada merupakan hal yang sangat penting untuk menunjang keberhasilan Pilkada itu sendiri, khususnya untuk menekan angka golput dan memberikan semacam penanaman nilai atau norma sosial sehingga bisa meminimalisi kecurangankecurangan dalam proses Pilkada itu sendiri.. Proses sosialisasi politik pada 
Pemilihan Bupati dan Wakil Bupati Tahun 2015 yang dilakukan oleh KPU Kabupaten Sijunjung dinilai sudah maksimal dengan cara mendatangi beberapa kampus, sekolah, maupun kelompok masyarakat tertentu. Tetapi Hasil Partisipasi masyarakat pada Pilkada Sijunjung Tahun 2015 masih berada pada angka 58, 48\% yang menunjukan bahwa angka partisipasi masyarakat dalam Pilkada Tahun 2015 ini lebih rendah dari partisipasi masyarakat pada tahun 2010 dan ini menjadi indikator bahwa sosialisasi yang telah dilakukan oleh KPU Sijunjung pada Pilkada 2015 belum berhasil untuk menekan angka golput dan meningkatkan Partisipasi pemilih.

Bertambahnya angka golput pada pemilihan Bupati dan Wakil Bupati Sijunjung tahun 2015 tersebut tentunya tidak bisa disalahkan pada proses sosialisasi politik semata. Karena dari penjabaran diatas, KPU Kabupaten Sijunjung telah berupaya dengan berbagai segmen dan program kegiatannya untuk mensosialisasikan Pilkada Sijunjung Tahun 2015 dengan maksimal. Bisa saja faktor apatisme masyarakat terhadap calon yang ada juga mempengaruhi hasil Pilkada tersebut. Tentunya ini bisa menjadi pertanyaan untuk diteliti selanjutnya.
Tetapi yang terus menjadi cacatan bagi KPU Kabupaten Sijunjung terkait proses sosalisasi politik yang dilakukan KPU adalah masih banyak pekerjaan rumah yang harus diselesaikan oleh KPU dalam proses sosialisasi politik ini, Kedepan KPU harus lebih intens dalam mensosialisasikan Pemilu yang bersih disamping dengan terus berupaya meminimalisir angka golput yang masih cukup besar. Inovasi dalam sosialisasi juga harus dilakukan KPU Sijunjung untuk menciptakan budaya baru dalam berdemokrasi. Termasuk didalamnya juga menggunakan media baru agar sosialisasi lebih hemat biaya dan lebih tepat sasaran. Kemudian KPU Sijunjung dalam bersosialisasi sebaiknya melakukan inovasi dengan bekerjasama dengan pihak-pihak terkait.

\section{Daftar Pustaka}

Budiardjo, Miriam. 2015. Dasar-Dasar Ilmu Politik cetakan 5. Jakarta. PT. Gramedia Pustaka Utama.

Damsar. 2011. Pengantar Sosiologi Politik. Lampung. Kencana Prenada.

Efriza, 2012. Political Explore: Sebuah Kajian Ilmu Politik, Bandung. Alfabeta.

Goode, William J. 2007. Sosiologi Keluarga. Jakarta. Bumi Aksara.

Hyman, Herbert. 1959. Political Socialization. A Study in the Psychology of Political 
Dedi Triralmaidi, Alfan Miko', Asrinaldi

Sosialisasi KPU Kabupaten Sijunjung Dalam Upaya Meningkatkan Partisipasi Pemilih Dalam Pilkada...

Behavior by Herbert H. Hyman. New York. Free Press.

Ihrom. 2004. Bunga Rampai Sosiologi Keluarga. Jakarta. Yayasan Obor Indonesia.

Kantaprawira,Rusadi. 2004. Sistem Politik Indonesia, Suatu Model Pengantar. Bandung. Sinar Baru Algensindo.

Kurnia, Ferry. 2007. Mengawal Pemilu Menatap Demokrasi : Catatan Penyelenggaraan Pemilu 2004. Jakarta. Idea Publishing.

Marijan, Kacung. 2010. Sistem Politik Indonesia: Konsolidasi Demokrasi Pasca-Orde Baru. Jakarta. Kencana Prenada Media Group.

Narwoko \& Bagong, 2007. Jakarta. Sosiologi Teks Pengantar dan Terapan. Kencana.

Prihatmoko, Joko J. 2005. Pemilihan Kepala Daerah Langsung, Pustaka Pelajar, Yogyakarta,

Rohendi Rohidi, Tjetjep. 2009. Analisis data kualitatif. Jakarta. Universitas Indonesia.

Sugiyono. 2012. Metode Penelitian Kuantitatif Kualitatif dan R\&D. Bandung. Alfabeta.

Surbakti, Ramlan. 1998. Memahami Ilmu Politik. Jakarta. Gramedia Widya Sarana.

Model DB1-kwk (rekapitulasi dan penghitungan perolehan suara) Pemilihan Bupati dan Wakil Bupati Kabupaten Sijunjung Tahun 2005.

Model DB1-kwk (rekapitulasi dan penghitungan perolehan suara) Pemilihan Bupati dan Wakil Bupati Kabupaten Sijunjung Tahun 2010.

Model DB1-kwk (rekapitulasi dan penghitungan perolehan suara) Pemilihan Bupati dan Wakil Bupati Kabupaten Sijunjung Tahun 2015. 